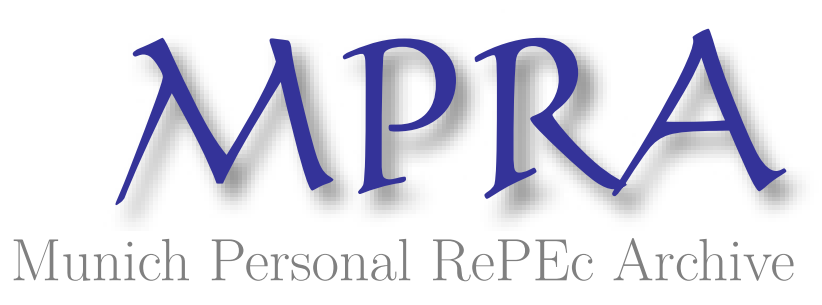

\title{
Trends of Rent-seeking Theory
}

Latkov, Andrey

October 2014

Online at https://mpra.ub.uni-muenchen.de/62864/

MPRA Paper No. 62864, posted 16 Mar 2015 13:33 UTC 
Latkov Andrey Vladimirovich, Doctor of Economics, Professor, Center of Psycho-Economic Researches of RAS Saratov Science Center, Head of rentseeking research laboratory (Saratov, Russia)

\section{Trends of Rent-seeking Theory}

Keywords: rent-seeking, "Virginian School", criticism, inputs, outputs, effects, trends

Summary. The article discusses the origin and development of the rentseeking theory. The interim results of the rent-seeking theory are summarized. The main trends in the rent-seeking theory development are presented in modern conditions.

Widespread rent-seeking in many socio-economic systems of virtually all countries has caused increased academics attention to agents' rent-seeking behavior in different spheres of society. Problems associated with rent-seeking are relevant for major semi-peripheral (China, India, Brazil, Mexico, Russia, etc.) especially. These countries are still not among the economically advanced states, and there is actual a "vicious circle of inefficient economic systems" for "developing countries" category according to a number of researchers. Rentseeking is an important link in this "vicious circle"[6].

Initially rent-seeking theory began to develop in the framework of the "Virginia School of Public Choice", whose members regularly publish their works in the pages of "Public Choice" science magazine. The term "rentseeking" was introduced in the scientific dictionary in the framework of this school, in fact [7]. "Rent-seeking activity" and "rent-seeking behavior" both are treated as synonyms. In addition, Virginia School achievements should include the "political economy of rent-seeking society" creation, integration of rentseeking theory and property rights theory [17], the basic rent-seeking model developing $[8,10,16]$, political agents' rent-seeking models creation in the political business cycle context $[1,5,9]$.

Rent-seeking is defined as a negative in its consequences for the public welfare traditionally, in accordance with the rent-seeking theory "mainstream", as part of the (often very large) resources rent-seeking agents are not directed to the goods output growth and distracted by the institutional conditions creation for reallocation of already created value in favor of the respective agent. This is evidenced by rent-seeking interpretation formulated by many researchers (see Table 1). 
Table 1. Treats of "rent-seeking"

\begin{tabular}{|c|l|}
\hline The authors & \multicolumn{1}{|c|}{ Treats } \\
\hline G. Tullock & $\begin{array}{l}\text { "The term rent seeking is designed to describe behaviour in institutional } \\
\text { settings where individual efforts to maximize value generate social } \\
\text { waste rather than social surplus" [14] }\end{array}$ \\
\hline R. Tollison & $\begin{array}{l}\text { Rent-seeking is "the expenditure of scarce resources to capture an } \\
\text { artificially created transfer" [13,p. 578] }\end{array}$ \\
\hline $\begin{array}{c}\text { G. Anderson, Ch. } \\
\text { Rowley, R. Tollison }\end{array}$ & $\begin{array}{l}\text { Rent-seeking is "the pursuit of profits via the use of government } \\
\text { coercion" [2, p. 100] }\end{array}$ \\
\hline $\begin{array}{l}\text { M. Brooks, } \\
\text { B. Heijdra, }\end{array}$ & $\begin{array}{l}\text { Rent seeking is "the use of resources to challenge existing property } \\
\text { rights" [3,p. 432] }\end{array}$ \\
\hline Ch. Rowley & $\begin{array}{l}\text { "Rent-seeking focuses attention on the resources expended by } \\
\text { competing interest groups in order to persuade governments to provide } \\
\text { returns higher than they could earn in the absence of government } \\
\text { protection" [11,p. 141] }\end{array}$ \\
\hline P. Fischer & $\begin{array}{l}\text { "In its most general form, rent-seeking describes the use of resources to } \\
\text { capture a "transfer' rather than to directly produce a good or service" [4, } \\
\text { p. 2] }\end{array}$ \\
\hline P. Fischer & $\begin{array}{l}\text { "Rent-seeking is an activity, usually implying the expenditure of scarce } \\
\text { resources, to cause and capture artificially-created (and usually } \\
\text { politically contestable) rents as well as transfers which are not part of } \\
\text { society's intended income redistribution" [4, p. 34] }\end{array}$ \\
\hline
\end{tabular}

Thus, dominating characteristics of rent-seeking behavior are the following in the tradition of the public choice school: a) the negative impaction to the social welfare; 2) the welfare redistribution area. Therefore, rent-seeking is defined as the attempt of individuals or groups to increase their own welfare, while making a negative contribution to the net society welfare. It means that some resources will not be consumed for productive purposes, but to the property rights structure change to favor of individuals or groups to obtain them in the form of surplus rents.

There are the distinctive characteristics rent-seeking in the scientific literature (see Table 2).

Table 2. Distinguishing features of rent-seeking and profit-seeking*

\begin{tabular}{|l|l|l|l|}
\hline \multicolumn{1}{|c|}{ Type of activity } & \multicolumn{1}{c|}{ Inputs } & \multicolumn{1}{c|}{ Outputs } & \multicolumn{1}{c|}{ Net effect } \\
\hline Profit-seeking & $\begin{array}{l}\text { Production costs of } \\
\text { labor, land, capital }\end{array}$ & $\begin{array}{l}\text { The final output of } \\
\text { goods and services }\end{array}$ & $\begin{array}{l}\text { Net value added (final } \\
\text { product gross value minus } \\
\text { production costs) }\end{array}$ \\
\hline Rent-seeking & Rent-seeking costs & $\begin{array}{l}\text { Economic rights as } \\
\text { the "rental results" }\end{array}$ & $\begin{array}{l}\text { Net rent-seeking effect (net } \\
\text { social gains minus rent- } \\
\text { seeking costs) }\end{array}$ \\
\hline
\end{tabular}

* Compiled by: [6, p. 3]

We should consider only the net social gain, which is formed as the agents rent-seeking activity result, during determining the net rent-seeking effect. 
Modern authors decipher rent-seeking costs as expenses in the process: a) lobbying; b) political activities; c) bribery and other "influencing effects". Rental results are the acquired, conserved, disturbed economic rights which were converted to the rents creation. Redistributed licenses, granting monopoly rights, subsidies, arising property rights are given as examples of the "rental results" usually [6].

The traditional interpretation of rent-seeking suggests that as a result of the economic agents rent-seeking society incurs losses of two types: losses due to inefficient administration of property rights and the production volume reduction due to waste of resources to obtain rents. These costs are higher than the amount of possible rent often. Thus, the direct losses due to agents' rent-seeking strategy measured value terms the overhead of creating the necessary and sufficient conditions for the redistribution of national income in the rental income form. Social losses due to rent-seeking illustrated by "Tullock rectangle" usually (see Figure 1).

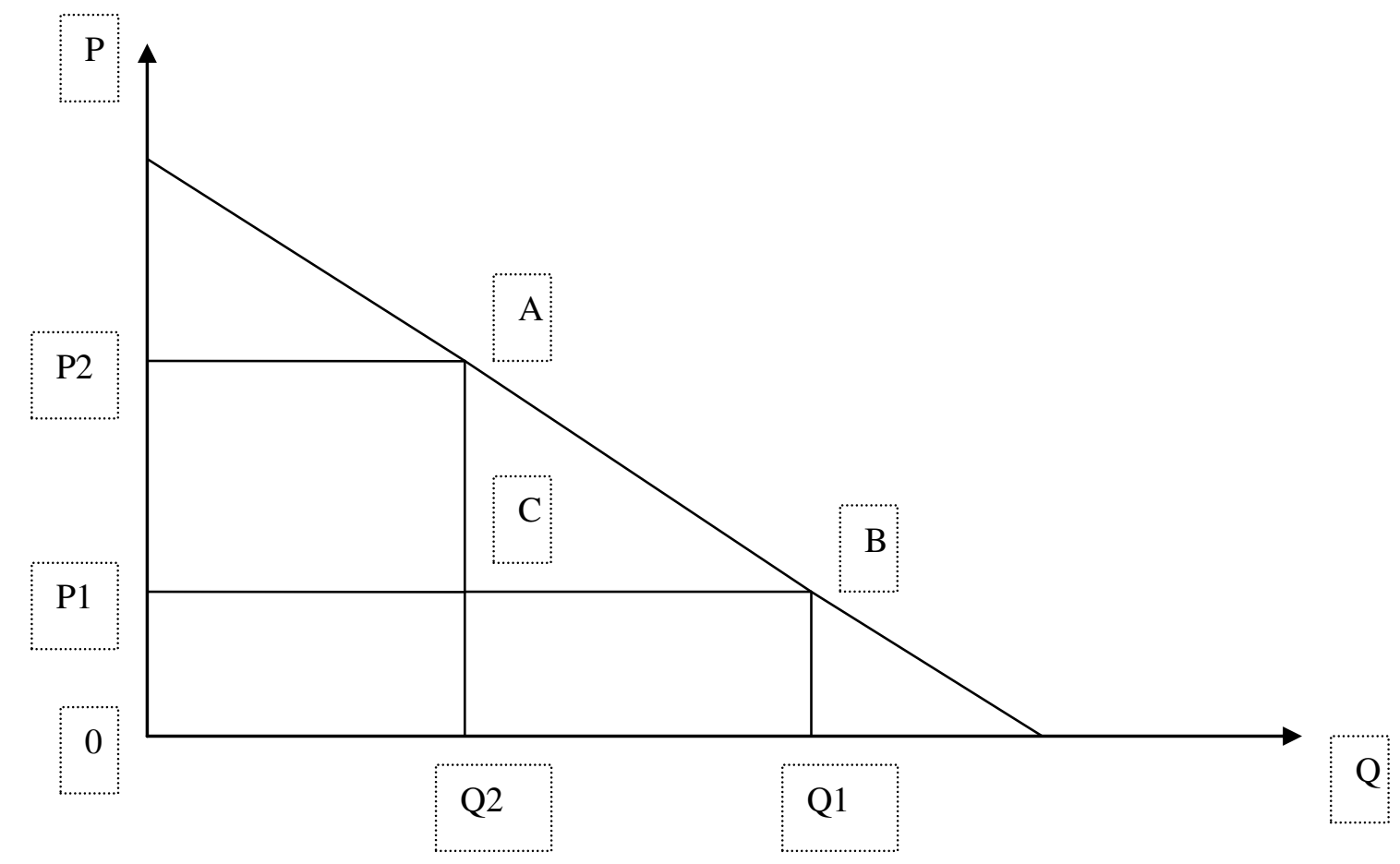

Figure 1. Redistribution of wealth as a result of market monopolization

The horizontal axis shows the quantity of goods, the vertical axis shows its price. Equilibrium price P1 will be realized amount Q1 of goods in the context of perfectly competitive market. In a monopoly context price rises to a value of $\mathrm{P} 2$, and the volume of its implementation is reduced to a value of Q2. Rectangle shows P1P2AC monopoly profits, i.e. value redistribution from consumers to the monopolist. In traditional economic theory the net society losses due to markets monopolizing are absent, because there is a simple reallocation from some society members (consumers) to the other society members (monopolies). American scientist Gordon Tullock and his followers proved incorrect this judgment. The fact that economic agents tend to expend resources to create 
monopoly position in the market. Thus in the successful case they spend at least a part of the resources corresponding to the rectangle area P1P2AC, but they may use these tools and even amount exceeding the area of the rectangle.

There may be competition between economic agents for a monopoly position achieving in the market. Losers also expend resources during rentseeking instead to invest in the goods production. Consequently, they have expended funds, which are redistributed to the competition winners, and the society as a whole has nothing to gain from their rent-seeking. In addition, the rent-seeking behavior is often accompanied by resistance to it. Also there is a resources waste in this case.

Rent-seeking is not limited by actions aimed to achieve a monopoly position in the market. Rent seeking occurs also in the cases of establishing maximum or minimum goods prices, during the foreign trade restriction, tax system change, etc. There is property rights redistribution bringing benefits to certain economic agents in these cases.

Table 3. Estimates of losses due to rent-seeking

\begin{tabular}{|c|c|c|c|}
\hline Experts & $\begin{array}{l}\text { The object of } \\
\text { research }\end{array}$ & $\begin{array}{l}\text { Institutional conditions } \\
\text { of rent-seeking }\end{array}$ & $\begin{array}{c}\text { Losses due to } \\
\text { rent-seeking }\end{array}$ \\
\hline A. Krueger & $\begin{array}{l}\text { Economy of India } \\
\text { in } 1964\end{array}$ & $\begin{array}{l}\text { Import licenses (quantitative control } \\
\text { over foreign trade) }\end{array}$ & $\begin{array}{l}7,3 \% \text { national } \\
\text { income }\end{array}$ \\
\hline A. Krueger & $\begin{array}{l}\text { Economy of Turkey } \\
\text { in } 1968 \\
\end{array}$ & $\begin{array}{l}\text { Import licenses (quantitative control } \\
\text { over foreign trade) }\end{array}$ & $15 \%$ GNP \\
\hline $\begin{array}{l}\text { S. Mohammad, } \\
\text { J. Whalley }\end{array}$ & $\begin{array}{l}\text { Economy of India } \\
\text { in 1980-81 }\end{array}$ & $\begin{array}{l}\text { The establishment of import and } \\
\text { export licenses, control of labor } \\
\text { markets, capital markets and goods } \\
\text { markets }\end{array}$ & $35-40 \%$ GNP \\
\hline $\begin{array}{l}\text { S. Mohammad, } \\
\text { J. Whalley }\end{array}$ & $\begin{array}{l}\text { Economy of Ghana } \\
\text { in } 1981\end{array}$ & $\begin{array}{l}\text { The establishment of import and } \\
\text { export licenses, control of labor } \\
\text { markets, capital markets and goods } \\
\text { markets }\end{array}$ & $18-21 \%$ GDP \\
\hline $\begin{array}{l}\text { S. Mohammad, } \\
\text { J. Whalley }\end{array}$ & $\begin{array}{l}\text { Economy of Ghana } \\
\text { in } 1984\end{array}$ & $\begin{array}{l}\text { The establishment of import and } \\
\text { export licenses, control of labor } \\
\text { markets, capital markets and goods } \\
\text { markets }\end{array}$ & $22-25 \%$ GDP \\
\hline $\begin{array}{l}\text { K. Koling, } \\
\text { D. Mueller }\end{array}$ & $\begin{array}{l}\text { Corporate sector in } \\
\text { the USA in 1963-66 }\end{array}$ & Private corporations rent-seeking & $\begin{array}{l}13 \% \text { «gross } \\
\text { corporative } \\
\text { product» }\end{array}$ \\
\hline $\begin{array}{l}\text { K. Koling, } \\
\text { D. Mueller }\end{array}$ & $\begin{array}{l}\text { Corporate sector in } \\
\text { the UK in } 1968-69\end{array}$ & Private corporations rent-seeking & $\begin{array}{l}7 \% \text { «gross } \\
\text { corporative } \\
\text { product» }\end{array}$ \\
\hline P. Posner & $\begin{array}{l}6 \text { sectors of the US } \\
\text { economy } \\
\text { (agriculture, } \\
\text { communications, } \\
\text { energy, banking, } \\
\text { insurance, } \\
\text { medicine, transport) }\end{array}$ & $\begin{array}{l}\text { State regulation (overstatement) of } \\
\text { prices }\end{array}$ & $\begin{array}{l}\approx 17 \% \\
\text { production } \\
\text { output }\end{array}$ \\
\hline
\end{tabular}


Attempts to economic losses identify due to rent-seeking undertaken by many scientists during the last third of the twentieth century. These losses were calculated both for the national economies of developing countries (India, Turkey, Ghana), and at the level of individual sectors and industry groups such highly developed countries like the USA and the UK (see Table 3).

There is criticism increasing of Virginia school, primarily affecting "Tullock rectangle" already in the 1980s. Critics have overestimated the loss of social welfare. First, it seems unlikely that rent-seekers use the whole "Tullock rectangle" to achieve monopoly status in the market. Secondly, the rent-seeking costs can have positive influence to welfare. The restrictions introduced in the models of rent-seeking lead to incorrect conclusions also, so the data models can not serve as the theoretical basis of the economic policy implementation $[12,15]$. However, this criticism does not extend beyond the "mainstream" theory of rentseeking.

Analysis of scientific publications over the past 25 years allows us to determine the current trends of development of the rent-seeking theory.

1. There is a specification of the category rent-seeking: it makes sense to distinguish between the rent-seeking behavior and rent-seeking activity. Thus, the development of the rent-seeking theory has the binary object of study.

2. Rent-seeking is investigated in the context of resource flows between such subjects "patron-client" network interactions as the bureaucracy, "capitalists", politicians, ordinary voters (Non-Capitalist Clients).

3. In order to approach the real models of national socio-economic systems it makes sense to research the rent-seeking in the coordinate system opening area of the spatial economy for the theory of rent-seeking behavior.

\section{References}

1. Alesina A., Roubini N., Cohen G. Political Cycles and the Macroeconomy, Cambridge, MA: MIT Press. 1997.

2. Anderson, Garry M.; Rowley, Charles K. and Tollison, Robert D. (1988). Rent-Seeking and the Restriction of Human Exchange. In: Journal of Legal Studies; Vol. 27, pp. 83100, January 1988.

3. Brooks, Michael A.; Heijdra, Ben J. and Lowenberg, Anton D. (1990). Productive Versus Unproductive Labor and Rent Seeking: Lessons from History. In: Journal of Institutional and Theoretical Economics; Vol. 146, Iss. 3, pp. 419-38, September 1990. P. 432.

4. Fischer, Pius (2004). Rent-Seeking, Institutions and Reforms in Africa: Theory and Empirical Evidence for Tanzania. PhD Thesis submitted to the University of Konstanz, Germany in January 2004. Edited version, September 2004 (minor corrections added in July 2005).

5. Haynes S., Stone J. Political Models of the Business Cycle Should Be Revived // Economic Inquiry. 1987. Vol. 28. P. 442-465.

6. Khan, M.H. and Jomo K.S. ed. (2000). Rents, Rent-Seeking and Economic Development: Theory and Evidence in Asia. Cambridge: Cambridge University Press, 2000. 
7. Krueger, A.O. (1974). The Political Economy of the Rent-Seeking Society, American Economic Review 64.

8. Nitzan S. Modelling Rent-Seeking Contests. - European Journal of Political Economy, 1994, vol. 10, No 1

9. Nordhaus W. The Political Business Cycle // Review of Economic Studies. 1975. Vol. 42. P. 169-189.

10. Posner, R.A. (1975). The Social Costs of Monopoly and Regulation, Journal of Political Economy 83.

11. Rowley, Charles K. (2000). Political Culture and Economic Performance in SubSaharan Africa. In: European Journal of Political Economy; Vol. 16, No. 1, pp. 133-58, March 2000.

12. Samuels, W.J. and Mercuro, N. 1984. A Critique of Rent-Seeking Theory, in Colander, D.C. (ed.) Neoclassical Political Economy: The Analysis of Rent-Seeking and DUP Activities. Cambridge Massachusetts: Ballinger Publishing Company

13. Tollison, Robert D. (1982). Rent Seeking: A Survey. In: Kyklos; Vol. 35, Iss. 4, pp. 575-602, 1982. P. 578.

14. Tullock, Gordon (1980). Efficient Rent-Seeking. In James M. Buchanan (ed.): Toward a Theory of the Rent-Seeking Society; A \& M University Press, Texas 1980.

15. Varian, H.R. (1989) Measuring the Deadweight Costs of DUP and Rent Seeking Activities, Journal of Economics and Politics, 81-95.

16. Познер Р. Экономический анализ права. СПб.: Экономическая школа, 2003.

17. Эггертссон Т. Экономическое поведение и институтыл. М: Дело, 2001. 